\title{
Mitigating Diabetes through Non-Invasive Management with Dental Air Force
}

\author{
Piero Policicchio* \\ CEO Air Force Inc, USA
}

Submission: April 24, 2018; Published: May 11, 2018

*Corresponding author: Piero Policicchio, CEO Air Force Inc, 933 Butternut Drive, Holland, MI 49424 USA, Tel: 616-218-7318/616-399-8511; Email: piero@dentalairforce.com

Keywords: Artificial sweeteners; Diet; Sucralose; Aspartame; Additive; Metabolism.

\section{Introduction}

It's not just what goes into your patients' mouth (like food and metformin) that helps control their blood sugar levels. It's also about what's going on with their mouth itself. The tissue surrounding their teeth has a surface area of approximately 9 square inches that is inaccessible to debridement by a toothbrush, floss and other conventional means. It is a palm size portal of entry into the body allowing bacterial pathogens to enter the bloodstream. The periodontal disease is a weeping wound. The body recognizes these organisms as infection with a vast array of associations to other systemic diseases such as diabetes, cardiovascular disease, stroke, Alzheimer's disease, COPD, chronic kidney disease, macular degeneration, impotence, children with low birth weight, peripheral artery disease, pancreatic cancer, lung cancer, colon cancer, esophageal cancer, and breast cancer. Hidden from physicians and other medical providers with little thought as to the consequences of not addressing this comorbidity, it is arguably the most costly disease in the world.

\section{Opinion}

Health care providers seeking the best quality of health care delivery for their patients are always looking for a solution to unmet needs that will assist them with providing better outcomes and cost savings to their patients. Periodontal disease has an effect on glucose metabolism as measured by HbA1c. Usually membrane-bound insulin receptors identify the presence of insulin in the blood which in turn regulates the blood sugar levels and activates glucose transporters bringing glucose into the cell for their metabolism and enzymatic production. However, in the presence of periodontal disease and chronic inflammation the formation of $\mathrm{C}$ reactive protein, cytokines (Interleukin-1, Interleukin- 6 and tumor necrosis factor) and other markers of inflammation disrupt the normal function and obstruct the insulin receptors. This impedes cellular glucose uptake. This cascade of events brings about insulin resistance to both diabetics and non-diabetics making glucose control difficult [1]. Complications occur and can be seen in other systemic diseases such as diabetes, cardiovascular disease, stroke, Alzheimer's disease, chronic kidney disease and macular degeneration [2].

Diabetes and periodontal disease have a bi-directional influence upon each other. People with diabetes are at a much higher risk of periodontal disease and people that have periodontal disease are at a higher risk for diabetes and its complications. The prevalence of periodontal disease in the general population is $50 \%$ for 35 year old and rises to $70 \%$ by age 65 [3]. The numbers are even more severe for those that are diabetic. Periodontal disease involves a heightened inflammatory host response and greater bone resorption, by osteoclastic action.

Periodontal disease is a biofilm disease that includes several pathogens (Pg, Aa, Fn, and Pi) triggering chronic systemic inflammation [4]. Mitigating these pathogens is the objective of periodontal therapy which lowers the host response of inflammation. However, after traditional periodontal therapy, the pathogen titers quickly reestablish themselves in the biofilm. A means to control this biofilm after periodontal therapy is necessary.

Dental Air Force is a device to assist in better outcomes for diabetic and cardiovascular patients. In one published six month study using Dental Air Force as an adjunct to periodontal therapy, a $1.04 \%$ reduction in $\mathrm{HbA1c}$ was observed in a population of 50 patients in Figure 1. A reduction also occurred in nondiabetics as well [5]. As a review, the British Medical Journal (BMJ) reported a $1 \%$ reduction in $\mathrm{HbA1c}$ levels gives the following reduction in combined diabetes-related endpoints [6]: 


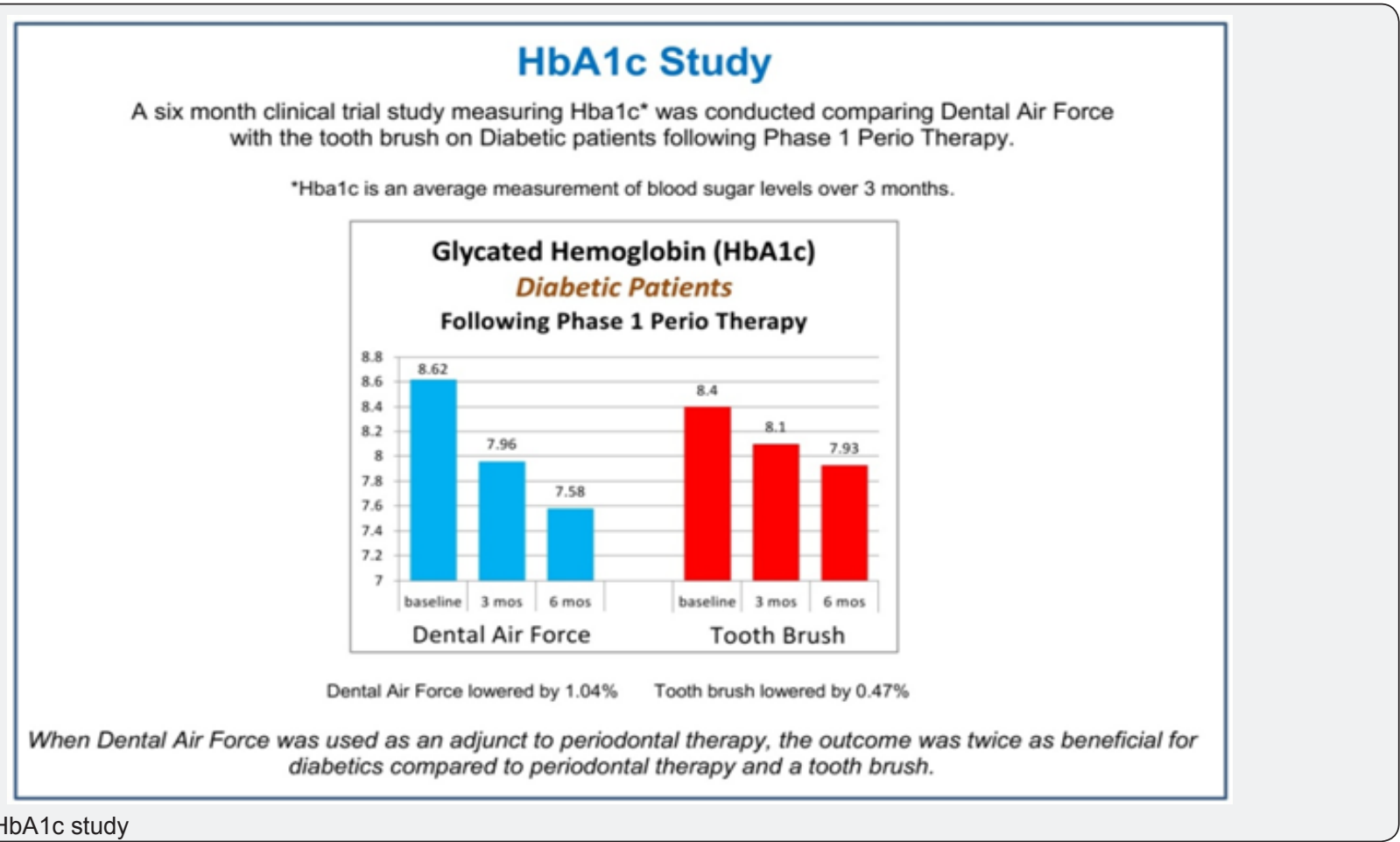

Figure 1: HbA1c study

1. $21 \%$ risk reduction for any endpoint related to diabetes

2. $21 \%$ risk reduction for deaths related to diabetes

3. $37 \%$ risk reduction in microvascular complications

4. $14 \%$ risk reduction in myocardial infarction

5. $43 \%$ risk reduction in amputations.

Dental Air Force is a non-invasive home management tool that has shown a reduction of $\mathrm{Pg}, \mathrm{Aa}, \mathrm{Fn}$, and Pi by $500 \%$ over the course of the study, unlike periodontal therapy followed by toothbrush maintenance [7]. It is an FDA approved for marketing medical device that mitigates the pathogens of periodontal disease that initiates a patient's chronic inflammatory host response Figure 2. New medical coding exists for the prescription of this medical device based on medical necessity $[8,9]$. It is up to the practitioner to utilize these codes to establish third-party payment for the patient.

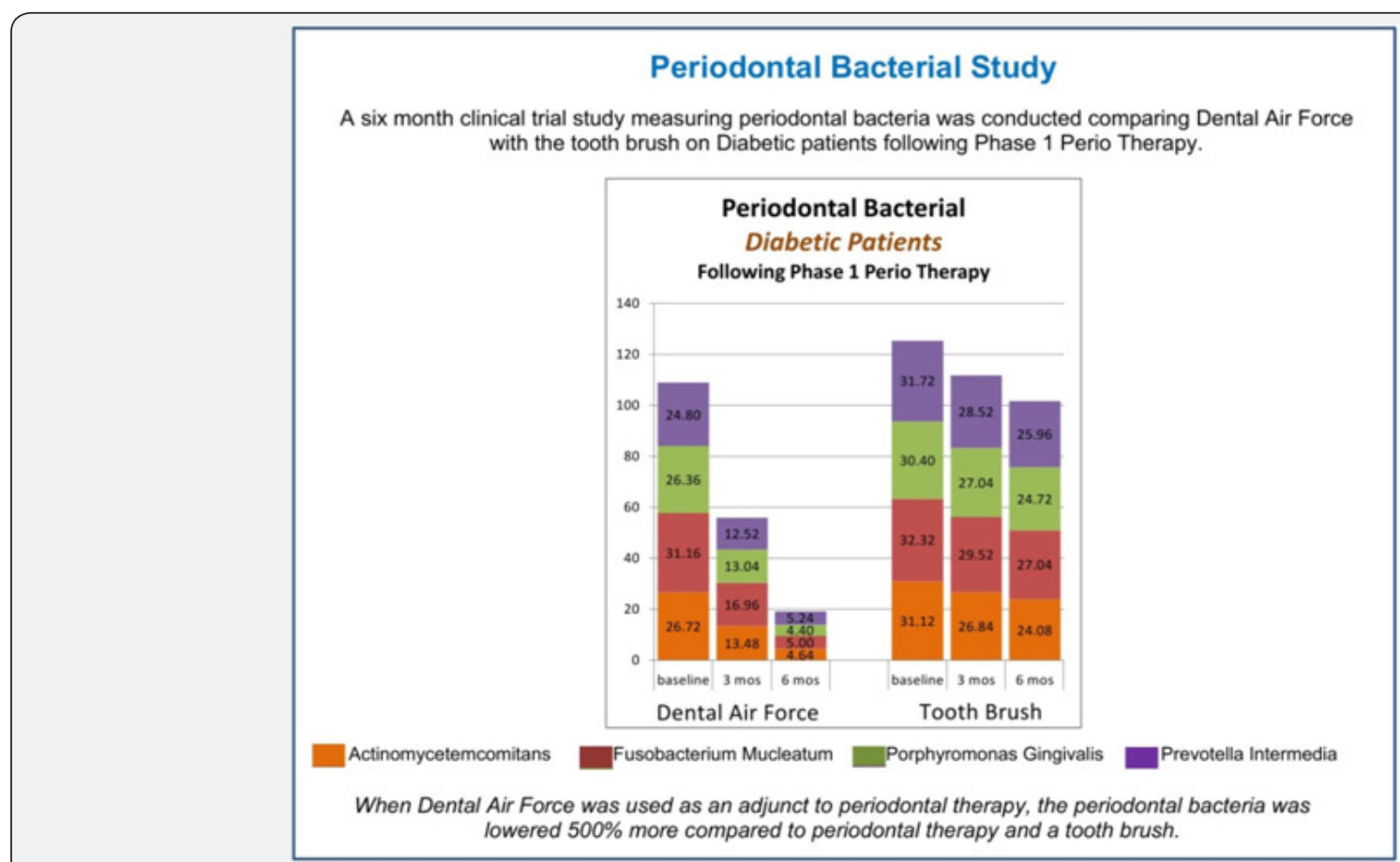

Figure 2: Periodontal bacterial study. 


\section{Current Research in Diabetes \& Obesity Journal}

\section{Disclosure}

P. Piero DDS is the CEO of Air Force Inc which manufactures the Dental Air Force.

\section{References}

1. (2016) Cell to cell communication -oral health and general health -the links between periodontitis, atherosclerosis and diabetes Quintessence Publishing Co, Europe.

2. Garcia RI, Henshaw MM, Krall EA (2001) Relationship between periodontal disease and systemic health. Periodontol 2000 25: 21-36.

3. Kornman KS (2012) CDC: Half of American adults have periodontal disease. Perio.org, American Academy of Periodontology.

4. Melvin WL, Assad DA, Miller GA, Gher ME, Simonson L, et al. (1994) Comparison of DNA probe and ELISA microbial analysis methods and their association with adult periodontitis. J Periodontol 65(6): 576582

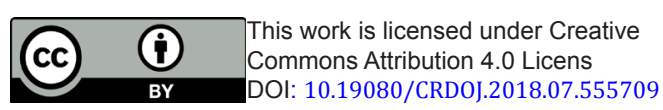

5. Mani A, Vadvadgi V, Anarthe R, Saini R, Mani S (2012) A Clinical study on dental air force home dental cleaning system on adult chronic periodontitis patients and its assessment to C-reactive protein levels. Int J Exper Dent Sci 1(1): 14-18.

6. Stratton IM, Adler AI, Neil HAW, Matthews DR, Manley SE, et al. (2000) Association of glycaemia with macrovascular and microvascular complications of type 2 diabetes (UKPDS 35): prospective observational study. BMJ 321: 405.

7. Mani A, Vadvadgi V, Anarthe R, Saini R, Mani S (2012) A Clinical study on dental air force home dental cleaning system on adult chronic periodontitis patients and its assessment to C-reactive protein levels. Int J Exper Dent Sci 1(1): 14-18.

8. (2018) ICD-10-CM Diagnosis Code E09.630 Drug or chemical induced diabetes mellitus with periodontal disease.

9. (2018) HCPCS Code E1399 Durable medical equipment, miscellaneous.

\section{Your next submission with Juniper Publishers will reach you the below assets}

- Quality Editorial service

- Swift Peer Review

- Reprints availability

- E-prints Service

- Manuscript Podcast for convenient understanding

- Global attainment for your research

- Manuscript accessibility in different formats

( Pdf, E-pub, Full Text, Audio)

- Unceasing customer service

Track the below URL for one-step submission https://juniperpublishers.com/online-submission.php 